\title{
The Role of Leadership in Managing Multicultural Teams. Polish Managers' Point of View: Preliminary Research
}

\author{
Rola przywództwa w zarzązaniu \\ wielokulturowymi zespołami. Punkł widzenia \\ polskich menedżerów - badania wstępne
}

\begin{abstract}
Today, in the globalized world of the 21 st century, the issue of leadership is topical and particularly important, hence it is not surprising that it is extensively analyzed in numerous publications. The role and significance of leadership primarily result from the fact that it has a great impact on the achievements of teams and companies, relations between people, their motivation to work, their openness to changes and new challenges, and a vision of the future development of the company.

The theoretical part of the article first explains the concept of leadership and its significance, and next describes multiculturalism as a challenge for contemporary leadership in the context of managing intercultural teams. The empirical part presents the methodology of the study and the results obtained, which are followed by conclusions and recommendations.
\end{abstract}

KEYWORDS

leadership, leader, multiculturalism, cultural diversity, multicultural teams

SLOWA KLUCZOWE przywództwo, przywódca, wielokulturowość, zróżnicowanie kulturowe, wielokulturowe zespoły

SPI Vol. 23, 2020/3

ISSN 2450-5358

e-ISSN 2450-5366 DOI: 10.12775/SPI.2020.3.002

Submitted: 15.06.2020 Accepted: 07.08.2020

Articles and dissertations 
The research described in the article (10 telephone interviews) was conducted with international companies among managers who work with culturally diverse teams. At this stage the research is preliminary, and the author intends to conduct an in-depth study among managers of multinational companies in Poland and Spain that will investigate the role of leadership in managing multicultural teams.

The main aim of the article is to demonstrate the importance of leadership in managing multicultural teams. Considering this aim, the following research question was formulated: How do Polish managers employed in multinational companies define leadership and how do they perceive the role of leadership in managing multicultural teams?

\section{ABSTRAKT}

Problematyka przywódzłwa jest szczególnie dziś, w XXI wieku w warunkach globalizacji, bardzo ważna i aktualna. Przywództwo jest szeroko analizowane w licznych publikacjach. Rola i znaczenie przywództwa wynika przede wszystkim z tego, że ma ono istotny wpływ na osiagnnięcia zespołów i firm, relacje między ludźmi, ich motywację do pracy, otwartość na zmiany i nowe wyzwania oraz kreowanie wizji przyszłego rozwoju firmy.

W części teoretycznej artykułu wyjaśniono pojęcie przywódzłwa oraz ¡ego znaczenie. Następnie opisano wielokulturowość jako wyzwanie dla współczesnego przywódzłwa w kontekście zarzq̨dzania międzykulturowymi zespołami. W dalszej kolejności przedstawiono metodologię i wyniki badań oraz wynikajqce z nich wnioski i zalecenia.

Badania opisywane w artykule (10 wywiadów telefonicznych) przeprowadzono w międzynarodowych przedsiębiorstwach wśród menedżerów, którzy zarzqdzaja zróżnicowanymi kulturowo zespołami. Na tym etapie badania majq charakter wstępny. Autorka planuje zrealizować pogłębione badania na temat roli przywództwa w zarzqqdzaniu wielokulturowymi zespołami wśród menedżerów przedsiębiorstw międzynarodowych w Polsce i w Hiszpanii.

Celem artykułu jest przede wszystkim wykazanie istotnego znaczenia przywództwa w zarzqdzaniu wielokulturowymi zespołami. Biorq̨ pod uwagę cel pracy, postawiono następujące pytanie badawcze: Jak polscy menedżerowie zatrudnieni w międzynarodowych przedsiębiorstwach definivja przywództwo oraz jak postrzegają rolę przywództwa w zarzqdzaniu wielokulturowymi zespołami? 


\section{Introduction}

Leadership in management, understood as the ability to influence employees' behaviour in order to achieve specific objectives, plays an important role, especially in managing multicultural teams. Leadership is based primarily on the authority of the individual - the manager - as well as the power that others, i.e. employees, voluntarily accept. Leadership involves setting the direction of action and development, developing a vision of the future of a given team and the whole organization, and directing people's actions towards the realization of common goals. People from totally different cultures frequently work together in multicultural work environments.

The effective management of a modern company and of the relations between employees, especially those working in multicultural teams, is achieved through effective leadership. Hence, the demand for leaders and their role and importance in modern management is constantly growing. Leaders are irreplaceable in motivating and inspiring employees, in solving conflict, in creating changes, and in building a vision of the future. Effective leaders in any organization, particularly the ones operating on an international scale, have a significant impact on the effectiveness of the work of individuals and entire teams.

Leadership is a subject of interest not only to researchers but also to practitioners, who observe that the increase of intercultural interactions in the activities of international companies requires leadership understood as a particular ability to inspire and release people's energy to act, overcome difficulties, take up new challenges, create change, and build competitiveness in a changing market.

The smooth functioning of modern organizations is possible thanks to leaders' relevant competences. It should be stressed, however, that leadership does not depend only on the personality traits and skills of the person who performs this role, but also on the conditions in which the organization functions. Therefore, leadership is particularly important in a multicultural environment. Leaders should be able to talk about the company's vision of development in a way that is clear and understandable to employees from different cultures, build positive relations inside intercultural teams and with clients, learn from their mistakes, share their knowledge, use 
employees' diverse experiences, give them attention, and appreciate their achievements.

Today, especially in companies operating in a multicultural environment, leadership should not be considered an optional choice but a necessity that empowers and directs their actions.

\section{Leadership - definitions and its significance}

The concept of leadership is not easy to define. Both the concept and leaders' tasks, roles, and competences have been evolving with the development of various fields of science, including sociology, psychology and management.

Leadership means to lead the way, to be the first, and to influence others with words and actions. It is also defined as the ability to point the way and the ability to activate and involve others in order to achieve a common goal.

Effective leadership is one of most essential parts of a range of methods used by an organization to sustain its business in the face of problems caused by the rapid growth of the economic environment (Cabeza-Erikson, Edwards and Van Brabant 2008).

John C. Maxwell (2013) and Jo Owen (2012) define leadership as influencing others. Joan Marques (2013) highlights the spiritual value of leadership and the need to introduce changes. Slawomir Lachowski (2013) describes it as the need to increase one's awareness and define one's own principles and values that a leader should follow in action. Ken Blanchard and Mark Muchnick (2013) offer several definitions of leadership, noting that it is not easy to give it a clear-cut definition. According to them, leadership is, among other things, the opposite of controlling and directing everyone to where they should be. Thus, it is about making the most of employees' potential. In defining leadership, Michael Williams (2013) indicates the need to adapt one's behaviour to a specific situation, while Brian Tracy and Robert Kozak (2012) pay attention to emotions that leaders evoke in employees and their characteristic features. In their opinion, leaders have a vision, attractive ideas, and see the best in people.

Peter G. Northouse (2007) and W. Glen Rowe (2007) argue that leadership is the process of influencing a group member to achieve a goal. According to John Naylor (1999), effective leadership 
is a product of the heart. An effective leader must be passionate, visionary, flexible, creative, innovative, inspiring, adventurous, courageous, and able to trigger change.

Other definitions describe leadership as a process during which leaders use their skills and knowledge to lead and direct a group of employees towards the desired direction that is relevant to their organization's goals and objectives (Jackson and Parry 2008) and also as a kind of power one person has to influence or change the values, beliefs, behaviours, and attitudes of another (Ganta and Manukonda 2014).

The analysis of other definitions reveals that leadership is also understood as the art of leading people to a goal, the pursuit of a vision, and the ability to encourage and inspire teams and people to act effectively.

It is worth emphasizing that in order to be a leader, it is not necessary to have a formally established authority or position, as leadership is the ability to effectively attract people and motivate them to act. Maxwell describes a leader as "the one who knows the way, follows it, and shows it to others" (quoted in Wilmanowicz 2012: 122). Northhouse (2009) states that leaders who possess strong leadership skills are able to influence others to achieve the goals and objectives of the organization.

Michael Williams points to the main features of effective leadership, which include: setting an example, building commitment through actions that create trust and team cohesion, educating future imaginative leaders, inspiring people to act effectively, creating a greater willingness to take risks and take on new challenges, keeping promises, building shared values and company success, and ensuring that the pace and scope of learning keep up with the pace of change in the environment and the actions of competitors (Williams 2009: 29).

It should also be mentioned that leadership is about supporting others. Leaders should strengthen employees' self-esteem and appreciate their ideas, knowledge and experience. Leadership also means the ability to solve conflicts, the ability to establish and maintain contacts within a team, and the ability to stimulate enthusiasm for working together and achieving common goals. 
According to Williams, leadership also embraces: communicating the vision and mission, influencing by inspiration, creating a great environment, crystallizing the aspirations and expectations of employees, engaging people in new visionary projects, building high performance ethics, as well as developing and using talent (Williams 2009: 33).

Wilmanowicz emphasizes that leaders make their teams aware of the goal. They answer questions about the motivation for actions and their benefits. They indicate the direction in which the team is heading and provide the guidance necessary for finding innovative solutions (Wilmanowicz 2012: 123).

It is claimed that in order to be a leader, one must have the knowledge, experience, patience, commitment and, most importantly, the skill to negotiate and work with others in order to achieve goals (Amanchukwu, Stanley and Ololube 2015).

The key factors that affect the effectiveness of leadership in organizations include integrity, usefulness, kindness, reciprocity and maintaining relationships. Integrity means the unity of thoughts, words and actions of a leader who should be honest and sincere towards employees. Usefulness is crucial in exerting influence. Employees should recognize and believe in the usefulness of their relations with the organization and the leader. Interactions must meet employees' expectations and be directed towards achieving common goals. Kindness means such relationships between a leader and employees that result in the contentment and satisfaction of both parties. Reciprocity means finding common grounds for action, taking action based on employees' ideas, and achieving goals based on clearly defined relationships. Maintaining relationships means maintaining a bond which enables efficient communication and action between the leader and employees. Employees should see the leader's commitment to their work and achievements and be aware that they are a valuable asset to their company (Zakrzewski, Zakrzewska and Brdulak 2014: 11627).

It is worth remembering that, in the 21 st century, leadership should be oriented towards results, process, the acquisition of knowledge and its effective application, releasing and developing employees' creativity, demonstrating the importance of integrity through action, seeking diversity, anticipating changes in the environment, 
viewing employees as critical resources, acting on the basis of global thinking, and investing in employees' continuous development (Ireland and Hitt 1999).

While talking about leadership, it is necessary to mention the concept of charismatic leadership, which occupies an important place in research conducted within organizational and managerial psychology. A charismatic leader is able to impress his/her employees and to win their obedience, especially in difficult situations. The leader can show the way out of a crisis and use an action plan in uncertainty. Charismatic leadership is based on a strong emotional bond between employees and their leader (Babiak 2008: 91-92).

Researchers of charismatic leadership conclude that this style of leadership, whose characteristic features include the leader's visionary nature, his/her ability to manage crises and to engage employees and gain their loyalty, exerts a significant impact on the quality of work, group effectiveness and organizational success (House and Aditya 1997).

When contemporary organizations adapt to the changing reality, they must implement improved ways of learning, shared knowledge and experiences, flexibility of action, diversity and innovative solutions. In order for organizations to be able to keep pace with a dynamic, changing environment, they need the ability to create a vision of the future that will allow them to effectively influence their employees. Therefore, leadership skills are among the most important skills necessary in modern organizations (Zakrzewski, Zakrzewska and Brdulak 2014: 11617). Leadership is a requirement of today, especially if the company operates in the international market and wants to be competitive.

"Effective leadership plays an important role in managing a business in the current business environment, for the old ways of business management are not enough to sustain a company in the modern market" (Hao and Yazdanifard 2015: 5). What is especially important is that "leadership skills also enable leaders to lead their employees into the correct direction, in accordance to the organization's vision and mission" (Hao and Yazdanifard 2015: 6).

Today's leadership should therefore be realized through positive, collaborative interactions based primarily on sharing knowledge and responsibility for the results achieved. 
Summarizing, it can be claimed that "functioning in a complex, rapidly changing world makes organizations appreciate the importance of leadership. It helps to shape development strategies and focus the attention of organizations and employees on the most important issues. Leadership helps to set borders and to empower employees and provides the necessary support" (Simerson and Venn 2010: 24).

\section{Managing intercultural teams - multiculturalism as a challenge in modern leadership}

Looking for new ways to grow and develop, contemporary companies expand their activities to international markets. To improve their competitive position in a global perspective, they implement new methods and solutions with a view to building their competitive advantage (Tiwarai 2013).

In today's business environment, the internationalization of business activity has become an indispensable condition leading to the growth and development of an organization. However, the internationalization of business activity requires companies to introduce changes to the ways in which they have previously operated (Đorđević 2016), particularly in the area of human resource management in the context of the cultural diversity of employees working in international companies.

It should be noted that due to globalization and the fact that enterprises increasingly function in an international business environment, the role and importance of leadership - especially leadership open to multiculturalism, which has become a must in modern management - are definitely growing. One of the causes of this growth is the fact that "diversity is more and more prevalent in modern workplaces. As a result, employees with different cultural backgrounds, nationalities, skills, and experiences come together and interact daily inside organizations" (Villotti, Stinglhamber and Desmette 2019: 246).

Multiculturalism in international companies is a normal phenomenon. However, cultural differences still pose a challenge for many leaders. The skilful management of these differences can maximize the benefits and minimize the problems resulting from cultural 
diversity. Multiculturalism is founded on the idea of cultural pluralism and on the notion of equality among all groups and respect for cultural diversity.

Multiculturalism has been defined as "a collection of diverse and interpenetrating cultures" (Jankowska-Mihułowicz 2011: 61) and as "a representation, in one social system, of people with distinctly different cultural backgrounds" (Cox 1993: 6). Multiculturalism can also be defined as an ideology that acknowledges and celebrates cultural differences (Arasaratnam 2013; Wolsko, Park and Judd 2006). Other researchers describe multiculturalism in terms of a pluralism of racial and ethnic groups (Fowers and Richardson 1996; Gay 2000; Watson 2002).

Managing intercultural differences has become imperative for global managers and modern leaders. "Understanding a business environment creates a basis for a competitive advantage, while successful adjustment to environmental changes is a necessary prerequisite for survival in the market" (Caganova, Cambal and Veidlichova Luptakova 2010: 51).

Intercultural interactions form a category strongly related to intercultural management; such interactions are the interactions of a person from one cultural background with a person from another cultural background or with other persons representing a different culture (Rozkwitalska 2011). Leaders working in international companies who manage culturally diverse employee groups are responsible for intercultural interactions in them. Whether and how a multicultural team will achieve its goals and succeed depends on leaders' knowledge, experience, interpersonal skills, openness and respect for cultural diversity.

One of the key advantages of a multicultural team is creativity, which develops on the basis of employees' diversity of knowledge and experience (Morgan 1989; Ochieng and Price 2009). Multicultural teams offer greater opportunities to operate effectively in international markets, and employees working in these teams and operating at the crossroads of different cultures contribute to recognizing and thus satisfying the needs of culturally diverse clients in a more effective way.

Multicultural teams positively affect the ability of an organization to adapt to various market situations, because employees who come 
from diverse cultural backgrounds can look at the same problem or situation from different perspectives (Cox and Blake 1991).

The advantages of multicultural teams also include working in an environment that is more open to representatives of diverse cultures and a greater acceptance of diversity. Therefore, intercultural management requires leaders who are tolerant and empathetic and able to build relations with employees from diverse cultures based on respect, understanding and trust.

The more culturally diverse teams are, the easier it is to observe equality, a lack of discrimination, fair treatment, integration and the prevention of exclusion in them. The benefits of working in multicultural teams include the cultural enrichment of the team and the reduction of ethnic tensions, as well as the opportunity to become familiar with new, diverse cultures and languages, to enrich one's own culture, to exchange information, thoughts and experiences, to increase one's tolerance, and to build a community (Ryszawy 2016).

It is worth mentioning that leaders should be able to identify and properly target the potential lying in multicultural teams (Pink 2012). However, leaders can manage their organization or team in different ways, for example, through cultural domination, cultural coexistence or cultural cooperation. Researchers observe that the most effective solution is cultural cooperation based on active and open impacts exerted by two cultures on each other, which can result in the creation of significant values, new experiences and positive cultural interactions. Thus, cultural diversity is definitely not an obstacle. It can be effectively employed as a valuable resource that leaders can use to support the international development of their organizations.

"Leadership in multicultural organizations, which are characterized by their employees' cultural diversity, should be open and flexible. It should create the conditions leading to a free exchange of opinions, experiences and ideas, to the search for new solutions, and to undertaking new challenges" (Knap-Stefaniuk and Burkiewicz 2018: 115).

It is good to realize that "effective intercultural management contributes to high effectiveness of global corporations. Organizations with 'learning' orientation are able to face intercultural management challenges. Relevant managerial challenges include cultural awareness, culture sensitivity, and flexibility to deal with diversity" (Caganova, Cambal and Veidlichova Luptakova 2010: 53). Therefore, 
leaders who work with multicultural teams should possess highly developed cultural intelligence, which is defined as a multidimensional structure that includes the individual's ability to function effectively in culturally diverse conditions (Earley and Ang 2003). Cultural intelligence is also defined as the ability of an individual to successfully adapt to new cultural contexts (Lovvorn and Chen 2011) or the ability of managers (leaders) involved in intercultural interaction to act effectively in a globalized world (Fang, Schei and Selart 2018).

"Effective leadership is essential in managing change, and change is the only method to sustain the organization in the current business environment (...). Therefore, leadership can be a factor to motivate and encourage people to continuously make change and push them to change. Leadership plays a role in an organization to motivate and encourage the employees to change in order for the organization to be able to sustain and adapt to the business environment, to make sure the organization will improve and be innovative" (Hao and Yazdanifard 2015: 7).

Leadership in contemporary organizations requires building strong relationships with employees based on mutual respect, trust and understanding. It requires shaping people's engagement by crossing boundaries of consolidated ways of thinking and acting. It also needs to be based on open, friendly communication and a passion for taking on new challenges together.

Leadership in a multicultural work environment requires respect for other people's cultural diversity and the adoption of perspectives and value systems that are very different from those of the leader.

\section{Methodology}

In her preliminary research, the author used the interview method in the form of the telephone interview technique due to the epidemiological situation related to COVID-19. The author prepared a short interview questionnaire in which she included closed and open questions to be answered by the respondents.

The criterion for selecting respondents was their employment in managerial positions in international companies and their management of multicultural teams (consisting of employees of at least two different nationalities working in the team led by a given manager). 
The interviews were conducted with ten managers from ten international companies. Five interviews were conducted with managers who work in companies from the IT sector that provide services in the area of the security, monitoring and management of IT infrastructure and in the area of comprehensive threat analysis. Another five interviews were conducted with managers from five international branches of companies that operate as shared service centres for human resource management and accounting services. All companies have their headquarters in Cracow and Warsaw.

The interviews were not recorded. During the interviews, the author wrote down the respondents' answers. The coding and categorization of empirical material were performed based on the interview questionnaire. A quantitative data analysis was also conducted.

The respondents participating in the interviews were of Polish nationality and were aged from 34 to 45 ( 3 women and 7 men). They were employed in the following managerial positions: International Sales Director (1 respondent), Marketing Director (1 respondent), Customer Service Manager (1 respondent), Key Account Manager (1 respondent), Senior Brand Manager (1 respondent), Product Manager (1 respondent), Marketing Manager (2 respondents) and Human Resource Manager (2 respondents). The research was conducted in May and June 2020.

\section{Leadership and its role in a multicultural work environment - preliminary research}

The author conducted ten interviews, which, as mentioned above, were of a preliminary nature. The research on the issues discussed in the present article is to be continued among Polish and Spanish managers.

The purpose of the interviews was to obtain information about whether the respondents (managers) know and understand the terms leadership and multiculturalism and whether they can describe the role of leadership in the management of multicultural teams and the challenges facing managers of multicultural teams in the area of leadership.

The author wanted to collect the opinions of managers working in international organizations about the role and importance of 
leadership in a multicultural work environment and to obtain information about whether the managers taking part in the interviews are familiar with issues in the field of leadership and multiculturalism (e.g. whether they have taken part in workshops or training in these areas).

The respondents comprised three women aged 34-38 and seven men aged 35-45. They all work in international companies and manage intercultural teams (employees of a minimum of two nationalities) and have worked in managerial positions for between three and ten years, and five of them have also worked in the structures of international companies outside Poland.

All respondents (10 positive answers) were familiar with the term leadership, which they understand as setting the direction of action and development of the team/company (10 respondents), developing a vision of the future of a given team and the whole organization (10 respondents), directing people's actions towards the realization of common goals (8 respondents), the art of leading people towards a goal (8 respondents), encouraging and inspiring teams and people to act effectively (7 respondents), skillfully using the potential of employees based on interesting ideas and creating a great working environment (7 respondents), crystallizing employees' aspirations and expectations (6 respondents), engaging people in new visionary projects (7 respondents), building high productivity ethics (5 respondents), and developing and using talents (7 respondents).

All respondents were also familiar with the term multiculturalism (10 positive answers). Multiculturalism understood as "a set of diverse interpenetrating cultures" was indicated by seven respondents and as "a group of people who are culturally diverse" by nine respondents.

All ten respondents agreed with the statement that leadership defined as "the particular ability to inspire and release people's energy to act, overcome difficulties and take on new challenges, create change, and build a competitive company in an international market environment" (the definition taken from the interview questionnaire) plays a crucial role in managing multicultural teams, which is something they observed in their companies in various areas. For example, this was observed in the open way of communicating with employees from diverse cultures (8 respondents), in conflict management (difficult situations) (7 respondents), in the way of motivating 
employees from diverse cultures (6 respondents), in engaging teams to create change ( 7 respondents), in building positive relations inside the teams and outside with customers (7 respondents), in investing in employee development ( 7 respondents), in supporting particularly talented employees (6 respondents), and in using the ideas, knowledge and experience of employees from diverse cultures to implement new solutions (6 respondents).

Only seven persons responded to the open question concerning challenges faced by leadership in managing multicultural teams. Their answers demonstrate that the following are treated as key challenges: education and development of leadership competencies/implementation of leadership development programmes in international structures (6 respondents), the continuous updating of knowledge about various cultures (6 respondents), building positive intercultural relations in teams based on mutual respect and understanding of cultural diversity (5 respondents), promoting talented employees in international structures (4 respondents), and organizing systematic training for managers and employees devoted to multiculturalism (6 respondents).

Among those who took part in the interviews, only half (5 respondents) had participated in training developing their leadership competencies, but as many as eight had participated in training on multiculturalism, which had mostly been devoted to communication and conflicts in multicultural teams regarding the cultures of their employees.

The majority of respondents taking part in the interviews (8 respondents) confirmed that leadership is very important in managing multicultural teams.

\section{Discussion}

The interviews were preliminary, and more in-depth research will be conducted in Poland and Spain among managers of international companies.

It should be noticed that all the managers (10 respondents) who participated in the survey were familiar with the terms leadership and multiculturalism. 
The respondents were of the opinion that leadership plays an important role in managing multicultural teams, which can be observed in various areas of management such as communication with employees, conflict management, motivating employees, engaging teams to create change, building positive relations, investing in employee development, supporting talented employees, and implementing new solutions based on the knowledge and experience of employees from diverse cultures.

The respondents also listed some challenges faced by leaders managing multicultural teams: developing leadership competencies, updating cultural knowledge, building intercultural relations in teams, developing talented employees, and organizing systematic training for managers in the field of intercultural (multicultural) management.

In the author's opinion, the respondents' knowledge of leadership and multiculturalism may be the result of workshops/training in which they had previously participated ( 5 respondents participated in those in the field of leadership and 8 in the field of multiculturalism).

\section{Conclusion}

The analysis of the subject literature devoted to leadership, multiculturalism and intercultural management, as well as the interviews conducted as part of this preliminary research, allow the author to demonstrate the significant role leadership plays in managing multicultural teams. In the near future, the author intends to continue her research in this area in Poland and Spain, thus expanding its cultural context.

In the author's opinion, effective functioning in the global market requires great openness and sensitivity in intercultural relations from contemporary leaders. Leaders who manage people in a multicultural environment must ensure that employees from different cultural backgrounds communicate effectively with one another, cooperate and share their knowledge and experience. It is necessary to accept co-workers' differences and different values, to get rid of stereotypical perceptions of people from different cultures, to learn mutual respect and tolerance, and to evoke the desire to understand representatives of other cultures. 
Leadership is indispensable for a more thorough understanding of foreign markets, customers and employees in terms of cultural diversity. Leaders are needed to inspire employees, release their potential and energy to act, create new solutions, take up difficult challenges, and build the future of their organization.

If modern organizations want to develop in an increasingly competitive, global environment, they must not only adapt themselves to the changing dynamics of this environment but also trigger and promote all their employees' creative and flexible actions and ideas. In order to become a dynamic, market- and customer-oriented organization that undertakes innovative and often difficult challenges, it is essential to have leaders who will be visionaries of the future and creators of change and who are able to appreciate and capitalize on the benefits of the effective work of multicultural teams.

\section{Bibliography}

Arasaratnam L.A. (2013). "A Review of Articles on Multiculturalism in 35 years of IJIR," International Journal of Intercultural Relations, vol. 37, pp. 676-685.

Amanchukwu R.N., Stanley G.J., Ololube N.P. (2015). "A Review of Leadership Theories, Principles and Styles and Their Relevance to Educational Management," Management, vol. 5, no. 1, pp. 6-14.

Babiak J. (2008). "Cechy przywódcze jako determinanty sukcesu organizacyjnego: odradzający się kierunek w badaniach przywództwa w organizacji," Przeglad Psychologiczny, vol. 51, no. 1, pp. 87-97.

Blanchard K., Muchnick M. (2013). Pigutka przywództwa. Brakujacy element motywujacy ludzi, Gliwice: Helion S.A.

Cabeza-Erikson I., Edwards K., Van Brabant T. (2008). Development of Leadership Capacities as a Strategic Factor for Sustainability, Karlskrona: Blekinge Tekniska Höogskola.

Caganova D., Cambal M., Weidlichova Luptakova S. (2010). "Intercultural Management - Trend of Contemporary Globalized World," Electronics and Electrical Engineering, no. 6(102), pp. 51-54.

Cox T.H. (1993). Cultural Diversity in Organizations: Theory, Research and Practice, San Francisco (CA): Berrett Koehler Publishers.

Cox T.H., Blake S. (1991). "Managing Cultural Diversity: Implications for Organizational Competitiveness," The Executive, vol. 5, no. 3, p. 47.

Đorđević B. (2016). "Impact of National Culture on International Human Resource Management," Economic Themes, vol. 54, no. 2, pp. 281-300. 
Earley P., Ang S. (2003). Cultural Intelligence: Individual Interactions across Cultures, Palo Alto (CA): Stanford University Press.

Fang F., Schei V., Selart M. (2018). "Hype or Hope? A New Look at the Research on Cultural Intelligence," International Journal of Intercultural Relations, vol. 66, pp. 148-171.

Fowers B.J., Richardson F C. (1996). "Why Is Multiculturalism Good?” American Psychologist, vol. 51, pp. 609-621.

Ganta V.C., Manukonda J.K. (2014). "Leadership During Change And Uncertainty In Organizations," International Journal of Organizational Behaviour \& Management Perspectives, vol. 3, no. 3, p. 1183.

Gay G. (1983). "Multicultural Education: Historical Developments and Future Prospects," Phi Delta Kappan, vol. 64, pp. 560-563.

Hao M.J., Yazdanifard R. (2015). "How Effective Leadership can Facilitate Change in Organizations through Improvement and Innovation," Global Journal of Management and Business Research: (A) Administration and Management, vol. 15, no. 9, pp. 1-7.

House R.J., Aditya R.N. (1997). “The Social Scientific Study of Leadership: Quo Vadis?” Journal of Management, vol. 23, no. 3, pp. 409-473.

Ireland R.D., Hitt M.A. (1999). "Achieving and Maintaining Strategic Competitiveness in the 21st Century: The Role of Strategic Leadership," The Academy of Management Executive, vol. 13, no. 1, pp. 43-57.

Jackson B., Parry K. (2008). A Very Short, Fairly Interesting and Reasonably Cheap Book About Studying Leadership, London: Sage.

Jankowska-Mihułowicz M. (2011). "Kształtowanie organizacji wielokulturowej - strategie Behawioralne," Problemy Zarzadzania, vol. 9, no. 4, pp. 61-74.

Knap-Stefaniuk A., Burkiewicz Ł. (2018). "Contemporary Leadership in the Context of Multiculturalism - Challenges for Human Resource Management," Scientia et Societas, vol. 14, no. 2, pp.113-122.

Lachowski S. (2013). Od wartości do dziatania. Przywództwo w czasach przetomowych, Warszawa: Wydawnictwo Studio Emka.

Lovvorn Al. S., Chen Jiun-Shiu (2011). "Developing a Global Mindset: The Relationship between an International Assignment and Cultural Intelligence," International Journal of Business and Social Science, vol. 2, no. 9, pp. 275-283.

Maxwell J.C. (2013). Bądź liderem, Warszawa: MT Business Ltd.

Marques J. (2013). Lider(ka) z krwi i kości. Świadome przywództwo, Sopot: Gdańskie Wydawnictwo Psychologiczne.

Morgan G. (1989). "Endangered Species: New Ideas,” Business Month, vol. 133 , no. 4, pp. 75-77.

Naylor J. (1999). Introduction to Operational Management, 2nd ed., Upper Saddle River (NJ): Prentice Hall.

Northouse P.G. (2007). Leadership Theory and Practice, London: Sage. 
Ochieng E.G., Price A.D. (2009). "Framework for Managing Multicultural Project Teams," Engineering, Construction and Architectural Management, vol. 16 , no. 6, pp. 527-543.

Owen J. (2012). Przywództwo. Biblia lidera, translated by M. Kowalczyk, Warszawa: Edgar.

Pink D.H. (2012). Drive: The Surprising Truth About What Motivates Us, New York: Riverhead Books.

Rozkwitalska M. (2011). Bariery w zarzadzaniu międzykulturowym. Perspektywa filii zagranicznych korporacji transnarodowych, Warszawa: Wolters Kluwer Business.

Rowe W.G. (2007). Cases in Leadership, London: Sage.

Ryszawy S. (2016). Wielokulturowość - szansa czy zagrożenie dla jednostki $i$ spoteczeństwa, Katowice: Wydawnictwo Uniwersytetu Śląskiego w Katowicach.

Simerson B.K., Venn M.L. (2010). Menadżer jako lider, Warszawa: Wolters Kluwer Business.

Tiwari N. (2013), "Managing Human Resources in International Organizations," Global Journal of Management and Business Studies, vol. 3, no. 4, pp. 355-360.

Tracy B., Kozak R. (2012). Wędrówkiz Gandalfem. Przywództwo, Warszawa: MT Biznes Ltd.

Williams M. (2009). Mistrzowskie przyzwództwo, Kraków: Wolters Kluwer Business.

Williams M. (2013). Przywództwo w świcie biznesu. Teoria i praktyka dla menedżerów, vol. 2, Warszawa: Wolters Kluwer S.A.

Wilmanowicz E. (2012). "Przywództwo jako kluczowa rola Top Managementu we współczesnych organizacjach," Studia i Prace Wydziatu Nauk Ekonomicznych i Zarzadzania, vol. 30, pp. 117-128.

Wolsko C., Park B., Judd C.M. (2006). "Considering the Tower of Babel: Correlates of Assimilation and Multiculturalism among Ethnic Minority and Majority Groups in the United States," Social Justice Research, vol. 19, pp. 277-306.

Zakrzewski B., Zakrzewska D., Brdulak J. (2014). "Przywództwo i jego rola w funkcjonowaniu przedsiębiorstwa logistycznego - ujęcie teoretyczne," Logistyka, vol. 6, pp. 11617-11629.

\section{ADDRESS FOR CORRESPONDENCE}

Agnieszka Knap-Stefaniuk

Jesuit University Ignatianum in Krakow

Institute of Political and Administrative Sciences

e-mail: agnieszka.knap.stefaniuk@ignatianum.edu.pl 